\title{
ART
}

\section{MODERN TECHNOLOGIES AS A COMPONENT OF THE RUNWAY SCENOGRAPHY}

\author{
Senior Teacher Kvasnytsya Roksolyana, \\ Ukraine, Lviv, Department of Design and Fundamentals of Architecture of Lviv Polytechnic National \\ University
}

\section{DOI: https://doi.org/ 10.31435/rsglobal_ws/28022019/6362}

\section{ARTICLE INFO}

Received: 10 December 2018

Accepted: 21 February 2019

Published: 28 February 2019

\section{KEYWORDS}

modern fashion shows,

light installations,

digital technologies.

\begin{abstract}
The subject of this article is determined by the need for an analysis of the lighting design and its application, specifically its aesthetic component, in fashion runway design. To analyse the application of modern lighting design techniques, namely light installations, 3D visualization, 3D and 4D holograms while preparing runways for fashion shows.
\end{abstract}

Citation: Kvasnytsya Roksolyana. (2019) Modern Technologies as a Component of the Runway Scenography. World Science.2(42), Vol.2. doi: 10.31435/rsglobal_ws/28022019/6362

Copyright: (C) 2019 Kvasnytsya Roksolyana. This is an open-access article distributed under the terms of the Creative Commons Attribution License (CC BY). The use, distribution or reproduction in other forums is permitted, provided the original author(s) or licensor are credited and that the original publication in this journal is cited, in accordance with accepted academic practice. No use, distribution or reproduction is permitted which does not comply with these terms.

Introduction. Every year, renowned fashion designers and major fashion houses present their new collections to the world by organising fancy shows featuring infinite flights of fantasy through scientific achievements and social trends for each new season. The history of fashion follows a dynamic spiral course of development which is characteristic to all historical processes.

In the twentieth and the early XXI century fashion and runway design have undergone significant changes. Continuous search for new ideas and experiments as well the development of modern technologies enable designers to create unforgettable performances, spectacular shows that undoubtedly deserve a thorough scientific analysis. Modern fashion shows use the latest technical accompaniments such as lighting design, audio techniques, decorations and pyrotechnics. Therefore lighting design is one of the most important visual elements which allow to achieve the most effective visual result.

Popular forms of light art (or luminism) are: light installations, use of one or several light sources in order to create a specific artistic effect or a certain image, as well as holograms and laser illumination. Light installations allow to simulate visual and spatial images during a fashion show and help create vivid and changeable compositions. [1,3]

The use of light installations in lighting design is rapidly expanding due to the existence of wide range of kinematic forms of visual information (media facades, video screens, dynamic architectural lighting, light and music shows, light and music fountains, space-simulation interactive light objects (light tunnels, arches, curtains), conceptual light installations, light typography, optical illusion, architecture, festive illumination, laser shows.

A wide range of light installations, in particular light projections, allows to create designs without modifying objects or surroundings, it allows to create an image. It changes the perception of reality without installing additional large-scale structures. It gives miscellaneous creative possibilities for graphic artists and designers. It also stimulates the symbiosis of different forms of art. 
The needed special effects are achieved when the appropriate compositional elements of light installations are used, such as rhythm/meter, scale, proportion, texture, dynamics/statics, color, contrast, chiaroscuro. In order to visually separate the front rows of the audience from the podium such rhythmically located light installations create a visual plane which can be either divided or where its length can be emphasized. The important factor in creating a general concept for a fashion show is the use and choice of colors. The appearance of different colors and the brightness of installations radically changes the perception of the environment as well as its zoning. [5]

Such techniques can simulate certain visual-spatial image, can change the perception of scale and proportions, can create dominance, place accents, emphasize dynamism or stativity. (Pic. 1)

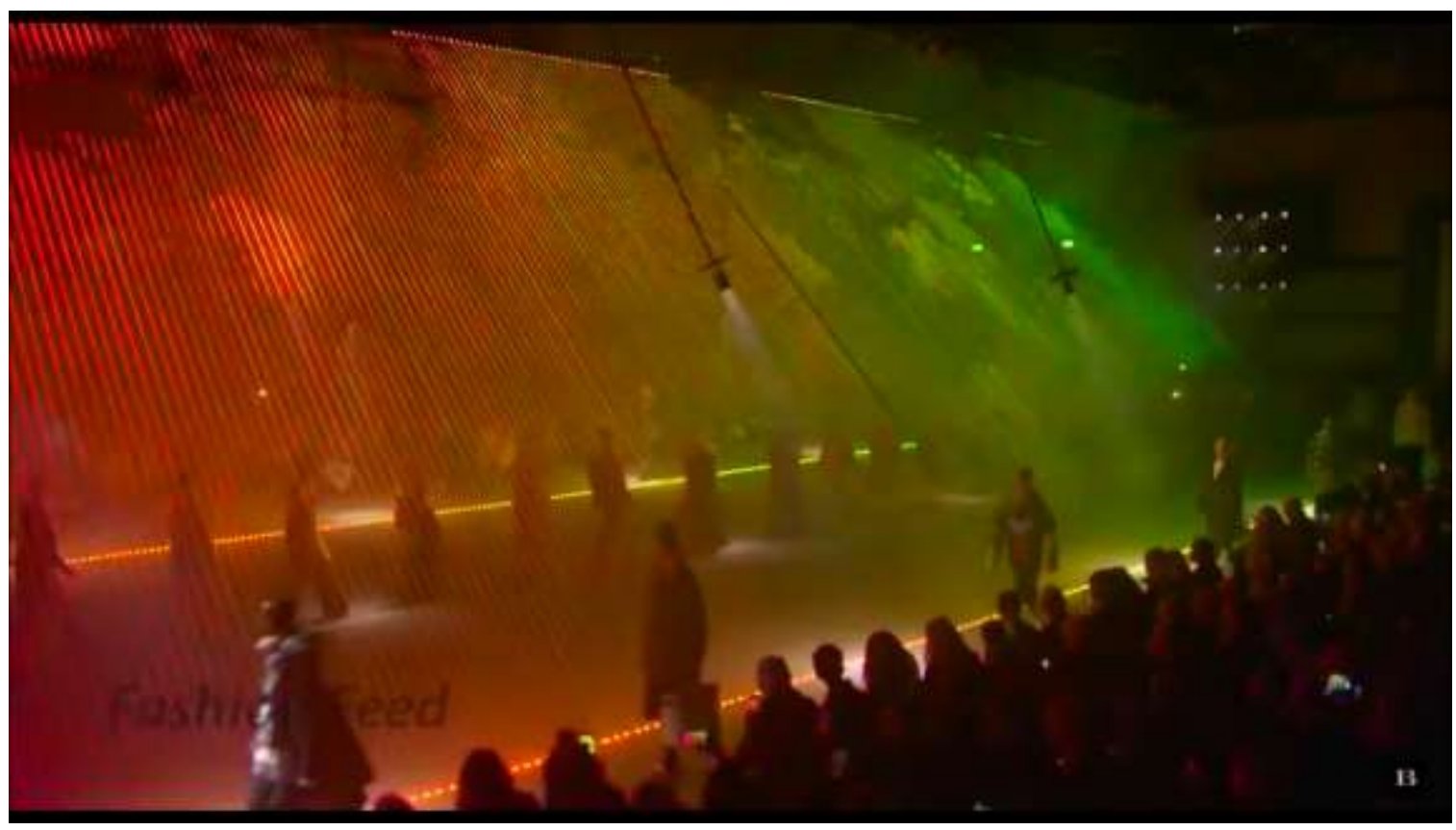

Fig.1. Burberry. London. 2018/2019. Designer - Christopher Bailey Retrieved from https://youtu.be/HQ5zkMIUDE

While certain elements are illuminated, highlighted in color, some decorative lighting accents are placed, other parts of the area remain dark. This creates a sensation of light and shadow, the focal and the secondary, and it forms an illusion of an objective real world with its essential and emotional characteristics.

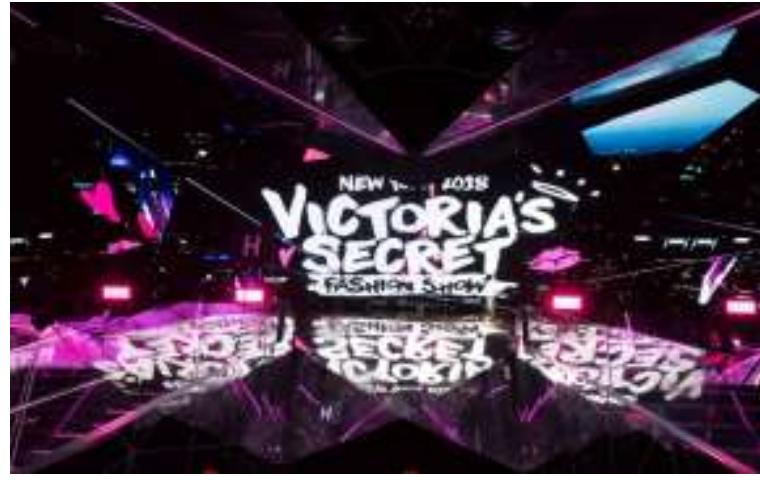

Fig.2 Victoria's Secret Fashion Show 2018 Retrieved from

http://composition.nyc/thumbs/compnyc/projects/sets/vs-3-1280x853.jpg

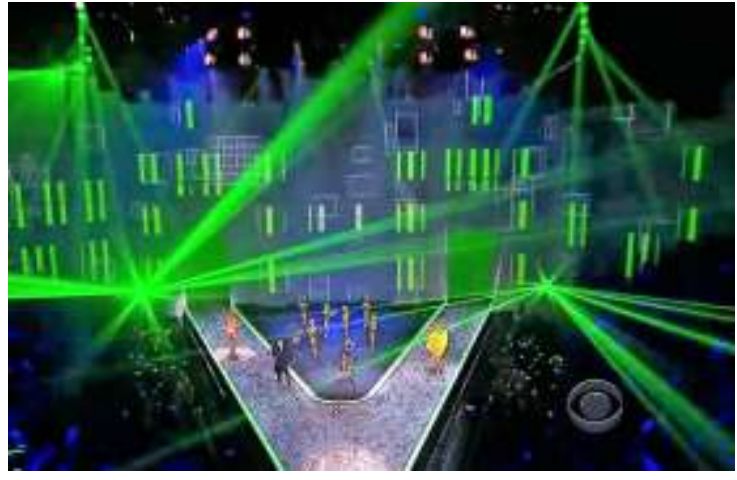

Fig.3 Victoria's Secret Fashion Show 2009 Retrieved from https://youtu.bel_TmXwQxADgc

A vivid example of using $3 \mathrm{D}$ visuals on stage and podiums are showcased during the Victoria Secret fashion presentations. (Pic. 2) Modern computer equipment capabilities help create 
photorealistic images, effectively implement artistic ideas and qualitatively broadcast 3D graphics onto large surfaces.

Another popular lighting technique is laser-based lighting where laser beams which are directed at different angles create the necessary forms and images. (Pic.3)

Since the emergence of the powerful projectors that make it possible to transmit high-quality images onto fairly large screens, designers have begun using the method of projecting slide shows, video clips and graphic collage images.

Such digital technologies as 3D and 4D holograms deserve special attention. These new technologies have created unique opportunities in the fashion show industry. Live models have been replaced by virtual images in order to create an unforgettable experience for the audience. A hologram creates a clever optical illusion, violates all rules of time and space, disorients the viewer.

As an example, let's take a look at the holographic show created by the artist from the video graphic, directed by Stefano Feyk and released on FAKE FACTORY (VIDEODESIGN studio in Florence, Italy). (Pic.4) Barcelona's largest holographic projection (40-meter holographic podium) was created and showcased during a show in Hotel Barcelona, the city of Barcelona.

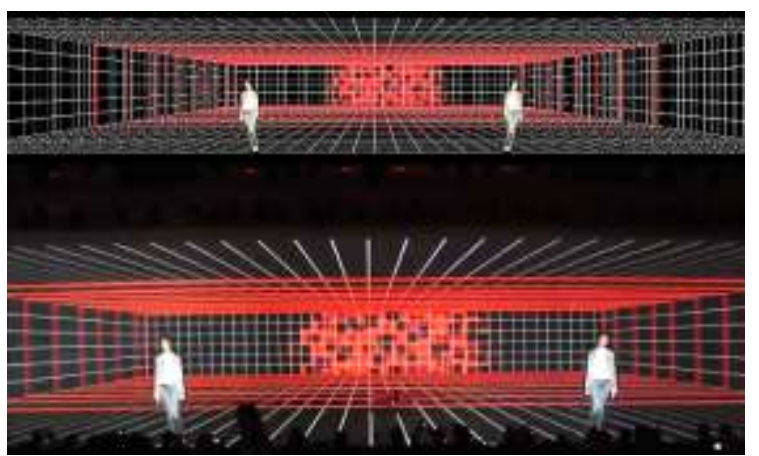

Fig.4. GUESS 3D. Barcelona, 2014. Video artist and director Stefano Fake

Retrieved from https://youtu.be/FNfwSsEC12E

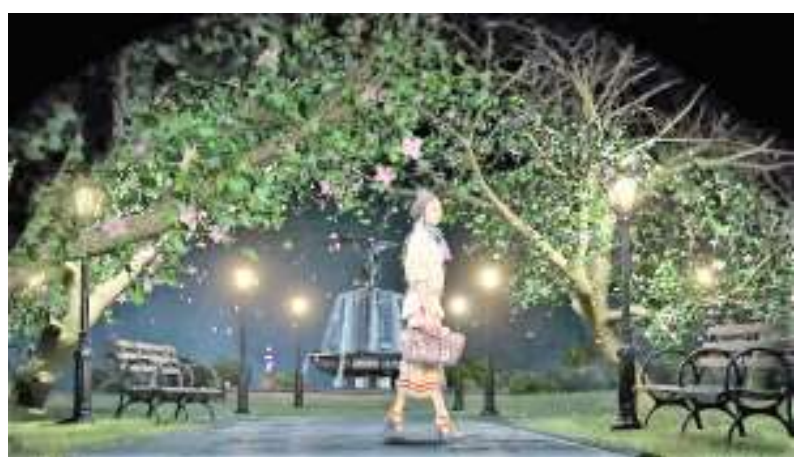

Fig.5. Ralph Lauren - 4D Holographic Fashion

New York. Manhattan's Central Park. 2015

Retrieved from https://youtu.be/Aab6nH8DV8g

One of the first to implement it was Alexander McQueen, later - Umberto Leon with Carol Lim. Holography has existed since the late 1940's and was refined in the 1960's after the laser inventions, but only in the last few decades holography has turned into something revolutionary. Despite the fact that this technology is used in many areas, fashion designers began to integrate it into their shows to create unique images that capture the audience and distinguish them from other designers, demonstrating incredible creativity $[4,6]$.

The concept of this fashion show was to create a kinematic show in which models up to $20 \mathrm{~m}$ come to life in the 4th dimension. The team used a combination of real shootings and videos with models rendered onto Cg-backgrounds. A total of 35,000 frames were used. This innovative fashion show which uses the latest technology has created an equally exciting 4D cinematic show, as the new Ralph Lauren collection presentation does. (Pic.5)

Conclusions. All these modern lighting design techniques form an overall feeling of dynamics and action on stage, specifically during fashion shows, focusing primarily on showcasing new collections presented by fashion models.

\section{REFERENCES}

1. Дубинский В. П. Интегрированное взаимодействие архитектурной и свето-цветовой среды современного города / Дубинский В. П. // Традиції та новації у вищій архітектурно-художній освіті, наук. збірник. вип. 1, 2, 3. - Харків, 2008. - С. 201-203.

2. Энджел Э. Интерактивная компьютерная графика / Э. Энджел. - М.: Вильямс, 2001. - Изд. 2. - 372 с.

3. Жаган В. Ілюмінація об’єктів / Жаган В. - Львів: ЕКО інформ, 2007. - 247 с.

4. Использование голографии в рекламе [В Интернете] // ЗАО «Голографическая индустрия» http://holography.by/infocenter/news/2009/175/. - (Cited 18.02.2019).

5. Кліщ О. А. Роль світла у формуванні образу міста / О. Кліщ // Креативний урбанізм: наук. монографія / ред. Б. С. Черкес, Г. П. Петришин. - Л.: НУ «Кліщ О. А. Роль світла у формуванні 
образу міста / О. Кліщ // Креативний урбанізм: наук. монографія / ред. Б. С. Черкес, Г. П. Петришин. - Л.: НУ «ЛП», 2014. - С. 595 - 600. ЛП», 2014. - С. 595 - 600.

6. Корешев С.Н. Основы голографии и голограммной оптики [Книга]. - СПб: СПбГУ ИТМО, 2009. стр. 97.

7. Люшер М. Цветовой тест Люшера. - М.: ЭКСМО, 2004. - 192 с.

8. Boyce P. R. Human factors in lighting / Boyce P. R. - London: Applied Science Publishers, 1981. - 703 p.

9. Derry T. K. A Short History of Technology from the Earliest Times to A.D. 1900 / Derry T. K., Williams T. I. / Paperback: Dover Publications, 1993. - 816 p.

10. Everett C. Judith, Swanson K. Kristen. Guide to Producing a Fashion Show. Bloomsbury, 2013. - c.20

11. M. Slinger C. Cameron C. Stanley Computer-Generated Holography as a Generic Display Technology [Journal] // Computer (38). - August 2005. - pp. 46-53.

12. THE DRAMATIC APPROACH OF I. HOFFMAN IN STRUCTURING THE SPACE OF FASHION. Available from: https://www.researchgate.net/publication/305078440_[accessed Nov 28 2018]. 